\title{
USE OF IoT AT BOSCH MANUFACTURING IN BANGALORE
}

\author{
Mallieswari R \\ Assistant Professor, Ramaiah Institute of Management, Bangalore, India \\ Aravinda Reddy M N \\ Assistant Professor, Ramaiah Institute of Management, Bangalore, India
}

\begin{abstract}
This paper empirically examines the Internet of Things (IoT) and its implementation on the business and manufacturing process, in the Bosch which is situated in Bangalore. This report has been developed as a guiding framework and conducted a series of research activities, including in-person workshops, virtual working group sessions, interviews of key thought leaders, and a survey of employ of Bosch manufacturing plant. Types of IoT application, IoT suite and IoT cloud-enabled software and the methods of IoT which is considered by the Bosch manufacturing process. Where Just in Time (JIT), Kaizon, Pokea-Yoke and Kanban are the major method of manufacturing process and to understand the impact of it by using chi square, which is focused more in this research and the use of IoT at bosch manufacturing in Bangalore.
\end{abstract}

Key words: Production process, Internet of Things (IoT), chi-square.

Cite this Article: Mallieswari R and Aravinda Reddy M N, Use of IoT at Bosch Manufacturing in Bangalore. International Journal of Management, 10 (1), 2019, pp. 33-37. http://iaeme.com/Home/issue/IJM?Volume=10\&Issue=1

\section{INTRODUCTION}

The Internet of Things (IoT) will transform companies and countries, opening up a new era of economic growth and competitiveness. We see a future where the intersection of people, data and intelligent machines will have far-reaching impacts on the productivity, efficiency and operations of industries around the world.

The Internet of Things (IoT) refers to the networking of physical objects through the use of embedded sensors, actuators, and other devices that can collect or transmit information about the objects. The data amassed from these devices can then be analyzed to optimize products, services, and operations.

\section{LITERATURE REVIEW}

Mukrimah Nawir, Amiza Amir, Naimah Yaakob, Ong Bi Lynn: (2016) brought out that the Internet of Things (IoT) comprises a complex network of smart devices, which frequently 
exchange data through the Internet. Given the significant growth of IoT as a new technological paradigm, which may involve safety-critical operations and sensitive data to be put online, its security aspect is vital. This paper studies the network security matters in the smart home, health care and transportation domains. It is possible that the interruption might occur in IoT devices during operation causing them to be in the shutdown mode.

Akshay Pardeshi, Shruti Bhadane, Rohidas Potangale, Hitesh Kudale, Department of Computer Engineering, SKNCOE (2016). His project includes implementation of the Home Automation System which can expose the data to the web so that user can access that data from anywhere. Home has heterogeneous distributed computing environment that is many equipment's are available in the home which can operate on different principals. Home automation is all about making your house smart. Just like the people for home to be smart it needs some information about the environment of home.

Xiaohui Wang and Nannan Liu, School of Management Science and Engineering, Shandong University of Finance and Economics, Jinan, China (2014). The aim of this article is to introduce the related technologies of internet of things and tries to build a model of Agricultural Means of Production Supply Chain based on it. Then it analyzes the function and utility of the internet of things applying on the agricultural means of production supply chain. Finally, the article describes the trends and prospects that the technology of internet of things in Agricultural Means of Production Supply Chain Objectives of the Study

Mahesh Kalmeshwar, Assoc. Professor Dr. Nandini Prasad K S (2017). Research on architecture standardization of IoT (Internet of thing) is going on, not yet concluded about standardization, it is still open and debatable how to make a standard platform. Thousands of researcher's and Engineers are concentrating on IoT architecture standardization. Few open source community have already started working on IoT architecture for standardization. Yet lot of improvement is needed. Even some organization are collaborating and coming up with standardization. This will give base IoT Architecture standardization or Initial architecture which can evolve one of the solutions for making standardization.

International Journal of Advanced Computer Science and Information Technology (IJACSIT) Vol. 3, No. 3, (2014). This article presents the design of a wireless communication system, responding to the sensor concept applied to a scaled industrial process where temperature variables were used. The sensors are connected to the internet (IoT) to be monitored remotely from anywhere in the world. The sensor data is downloaded from the cloud using a graphical programming platform to control and communicate the system with a programmable logic controller (PLC), which performs the actions according to the temperature value (set point) of the sensors

\section{OBJECTIVE OF THIS RESEARCH}

- To understand the methods used for IoT in manufacturing process.

- To understand the tools and model of IoT devices used in manufacturing process.

- To understand the process where IoT is used.

\section{SCOPE OF THE STUDY}

This study focuses on to understand the method of manufacturing process which is affected most by the use of IoT. Which are the Bosch IoT Suite service available in Bosch IoT Cloud. This research is conducted on use of Internet of Things (IOT) at Bosch manufacturing company, Bangalore to understand to the process IoT is used and how it affect the manufacturing process. 


\section{HYPOTHESIS}

The following hypothesis have been made.

$\mathrm{H}_{0}$ : The Internet of Things (IoT) significantly impacts the manufacturing process of the company.

$\mathrm{H}_{1}$ : The Internet of Things (IoT) does not have an impact on the manufacturing process of the company.

\section{DATA AND METHODOLOGY}

Although manufacturing process are impacted by many factors, the research incorporates four very basic production process that affect the output. They are Just in Time (JIT), Kaizon, PokeaYoke and Kanban.

Secondary Data is used. Cloud enabled software package for developing application in IoT us used.

They are IoT Analytics, IoT Rollout, IoT Hub.

Sampling technique used- Convenient Sampling Sample size- The study covers IoT and tools used at Bosch manufacturing units in Bangalore.

The chi-square is used to identify the production process is highly effective with the use of IoT.

\section{ANALYSIS, RESULTS AND DISCUSSIONS}

Table 1

Just In Time (JIT)

\begin{tabular}{|c|c|c|c|}
\hline & $\begin{array}{c}\text { Observed } \\
\text { N }\end{array}$ & $\begin{array}{c}\text { Expected } \\
\text { N }\end{array}$ & Residual \\
\hline Very low & 6 & 10.0 & -4.0 \\
Low & $\cdot$ & 10.0 & -8.0 \\
Average & 6 & 10.0 & -4.0 \\
High & 9 & 10.0 & -1.0 \\
Very high & 27 & 10.0 & 17.0 \\
Total & 50 & & \\
\hline
\end{tabular}




\section{PokeaYoke}

\begin{tabular}{|c|c|c|c|}
\hline & $\begin{array}{c}\text { Observed } \\
\mathbf{N}\end{array}$ & $\begin{array}{c}\text { Expected } \\
\mathbf{N}\end{array}$ & Residual \\
\hline Very & 4 & 10.0 & -6.0 \\
low & 22 & 10.0 & 12.0 \\
Low & 10.0 & .0 \\
Average & 10 & 10.0 & 3.0 \\
High & 13 & 10.0 & -9.0 \\
Very & 1 & & \\
high & & & \\
Total & 50 & &
\end{tabular}

Kanban

\begin{tabular}{|c|c|c|c|}
\hline & $\begin{array}{c}\text { Observed } \\
\mathbf{N}\end{array}$ & $\begin{array}{c}\text { Expected } \\
\mathbf{N}\end{array}$ & Residual \\
\hline Very & 8 & 10.0 & -2.0 \\
low & & 10.0 & -4.0 \\
Low & 6 & 10.0 & 5.0 \\
Average & 15 & 10.0 & 3.0 \\
High & 13 & 10.0 & -2.0 \\
Very & 8 & & \\
high & 50 & & \\
Total & 50
\end{tabular}

Test Statistics

\begin{tabular}{|c|c|c|c|c|}
\hline & $\begin{array}{c}\text { Just In } \\
\text { Time (JIT) }\end{array}$ & Kaizon & PokeaYoke & Kanban \\
\hline $\begin{array}{c}\text { Chi- } \\
\text { Square } \\
\text { df }\end{array}$ & $38.600^{\mathrm{a}}$ & $18.000^{\mathrm{b}}$ & $27.000^{\mathrm{a}}$ & $5.800^{\mathrm{a}}$ \\
$\begin{array}{c}\text { Asymp. } \\
\text { Sig. }\end{array}$ & 4 & 3 & 4 & 4 \\
\hline
\end{tabular}

a. 0 cells $(0.0 \%)$ have expected frequencies less than 5 . The minimum expected cell frequency is 10.0 .

b. 0 cells $(0.0 \%)$ have expected frequencies less than 5 . The minimum expected cell frequency is 12.5 . 


\section{INTERPRETATION AND HYPOTHESIS TESTING}

\section{Hypothesis}

The test statistics of chi-square indicate missing value of 0.215 it is greater than 0.05 and hence null hypothesis accepted. There for it is concluded that The Internet of Things (IoT) significantly impacts the manufacturing process of the company

\section{CONCLUSIONS}

This study reveals how the Internet of Things (IoT) is changing the way many companies do business. Traditional manufacturers are integrating their physical products with internet based backend services, and internet companies are extending their offerings by integrating data from sensors and physical assets. New companies are entering the market with IoT offerings that combine physical products with internet based services. Sensor-generated data and machine learning solutions enable new, data-driven business

\section{REFERENCES}

[1] Mukrimah Nawir „Amiza Amir, Naimah Yaakob, Ong Bi Lynn:“Internet of Things (IoT) - Taxonomy of security Attacks.2016 3rd International Conference on Electronic Design (ICED), August 11-12, 2016.

[2] Manan Mehta. ESP 8266: A Breakthrough in Wireless Sensor Networks and Internet of things. International Journal of Electronics and Communication Engineering \& Technology, 6(8), 2015, pp. 07-11.

[3] Akshay Pardeshi, Shruti Bhadane, Rohidas Potangale, Hitesh Kudale, IJSRD International Journal for Scientific Research \& Development,| Vol. 4, Issue 03, 2016,pp 360-361

[4] Chandrashekhar Kalnad, Review on The Internet of Things (A Thing of The Future). International Journal of Advanced Research in Engineering and Technology, 7(4), 2016, pp 30-36

[5] Xiaohui Wang and Nannan Liu, The application of internet of things in agricultural means of production supply chain management, Journal of Chemical and Pharmaceutical Research, 6(7) 2014, pp 2304-2310

[6] Settapong Malisuwan and Wassana Kaewphanuekrungsi, Technological Factors Promoting the Expansion of Internet of Things. International Journal of Advanced Research in Engineering and Technology, 7(2), 2016, pp. 21-29.

[7] Mahesh Kalmeshwar, Dr. Nandini Prasad K S, Dr.AIT, Internet of Things: Architecture, Issues and Applications, Journal of Engineering Research and Application, Vol 7 Issue 6, 2017, pp $85-88$.

[8] Salakapuri Rakesh and Prof. Nagaratna P Hegde, Internet of Things and Big Data Analytics for Developing Smart Cities: A Review. International Journal of Computer Engineering and Technology, 9(3), 2018, pp. 42-46.

[9] Juan Felipe Corso Arias, Yeison Julian Camargo Barajas and Juan Leonardo Ramirez Lopez, Wireless Sensor System According to the Concept of IoT -Internet of Things, International Journal of Advanced Computer Science and Information Technology (IJACSIT) Vol. 3, No. 3, 2014, Page:327-343

[10] R. Raghavan, John Singh. K, Thippa Reddy G, Sudheer K and Venkatesh P and Stephen Olatunde Olabiyisi, A Case Study: Home Environment Monitoring System using Internet of Things, International Journal of Mechanical Engineering and Technology 8(11), 2017, pp. 173-180. 